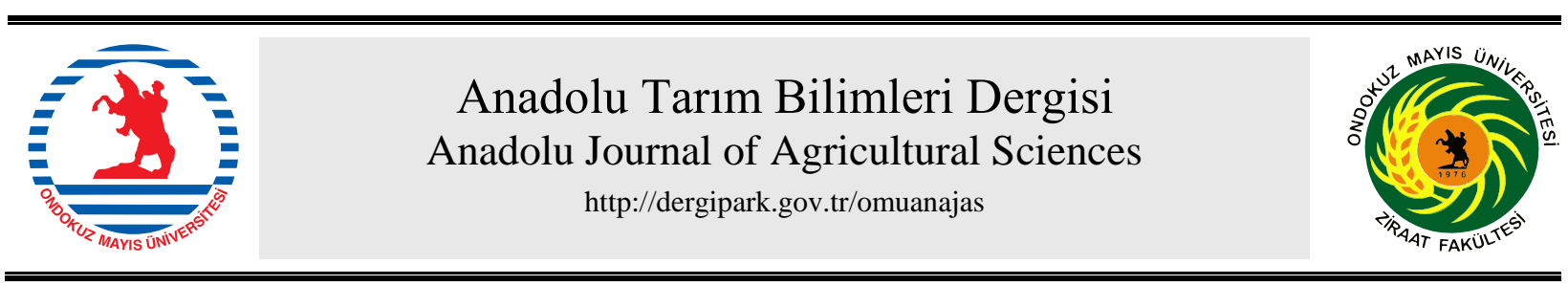

Araştırma/Research

Anadolu Tarım Bilim. Derg./Anadolu J Agr Sci, 36 (2021) ISSN: 1308-8750 (Print) 1308-8769 (Online) doi: 10.7161/omuanajas.845088

\title{
Hidroponik mürdümük üretimde bitkisel kaynaklı duman solüsyonlarının etkisi
}

\author{
Medine Çopur Doğrusöz ${ }^{\mathrm{a}^{*}}$, ๑ Uğur Başaran ${ }^{\mathrm{a}}$, ๑ Erdem Gülümser ${ }^{\mathrm{b}}$, ๑ Hanife Mut ${ }^{\mathrm{b}}$ \\ ${ }^{a}$ Yozgat Bozok Üniversitesi, Ziraat Fakültesi, Tarla Bitkileri Bölümü, Yozgat, Türkiye \\ ${ }^{b}$ Bilecik Şeyh Edebali Üniversitesi, Ziraat ve Doğa Bilimleri Fakültesi, Tarla Bitkileri Bölüm, Bilecik, Türkiye \\ *Sorumlu yazar/corresponding author: medine.copur@bozok.edu.tr
}

Geliş/Received 22/12/2020～Kabul/Accepted 28/04/2021

\section{ÖZET}

$\mathrm{Bu}$ çalışma bitki kaynaklı duman solüsyonlarının hidroponik ortamda yetiştirilen mürdümüğün (Lathyrus sativus L.) yem verimi ve kalitesi üzerine etkisini incelemek amaciyla yürütülmüştür. Mürdümük tohumları iki farklı bitkinin (yulaf ve mürdümük) yakılmasıyla elde edilen duman solüsyonlarının 5 faklı konsantrasyonu ile priming işlemine tabi tutulmuştur. Çalışma duman solüsyonu kaynağına göre iki farklı deneme olarak yürütülmüştür. Priming sonrasında hidroponik ortamda yetiştirilen mürdümükte sekizinci günün sonunda verim, ham protein oranı, ham protein verimi, ADF, NDF ve mineral madde içerikleri incelenmiştir. Hidroponik mürdümük filizlerinde taneye oranla kuru ağırlık kaybı gerçekleşmiş ve bu kayıp duman solüsyonu uygulaması ile azaltmıştır. Duman solüsyon uygulamaları kimyasal özellikler üzerinde de olumlu sonuçlar doğurmuş, yulaf kaynaklı duman solüsyonu protein oranı ve protein verimi, mürdümük kaynaklı solüsyon ise mineral madde içerikleri üzerinde daha ekili olmuştur. $\mathrm{Bu}$ çalışma, duman solüsyonunun mürdümügün hidroponik ortamda gelişmesini teşvik ettiğini ancak, bu durumunun duman solüsyonu kaynağına ve konsantrasyonuna bağlı olarak değiştiğini göstermiştir.

\section{The Effect of Plant-Derived Smoke Solutions in Hydroponic Grass Pea Production}

\section{ABSTRACT}

This study was carried out to examine the effect of plant-derived smoke solutions on feed yield and quality of grasspea (Lathyrus sativus L.) grown in hydroponic environment. Grasspea seeds were primed with 5 different concentrations of smoke solutions obtained by burning two different plants (oat and grasspea). The study was conducted in two different trials according to the source of smoke solution. The yield, crude protein ratio, crude protein yield, ADF, NDF and mineral matter contents were examined at the end of the eighth day in the seedlings grown in hydroponic environment after priming. In the hydroponic sprouts, a loss of dry weight compared to the grain has occurred and this loss has been reduced with the application of smoke solution. Smoke solution applications have also had positive results on chemical properties; oat-sourced smoke solution has been more effective on protein ratio and protein yield, and grasspea-sourced solution on mineral substance contents. This study showed that the smoke solution promotes the growth of grasspea in a hydroponic environment, but this situation changes depending on the source and concentration of the smoke solution.
Anahtar Sözcükler:

Mürdümük,

Hidroponik yem,

Duman solüsyonu,

Protein

Keywords:

Grasspea,

Hydroponic Forage,

Smoke solution,

Protein

(C) OMU ANAJAS 2021 


\section{Giriş}

Hidroponik yem üretim sistemi topraksız ortamda sadece bitki tohumlarının çimlendirilmesi esasına dayalı alternatif bir kaba yem üretim metodudur. Kısa sürede besin değeri yüksek, düşük maliyetli taze yem sağlayan bu sistem sayesinde y1lın her mevsiminde yeşil yem üretimi mümkün olmaktadır.

Hidroponik sistemde, çoğunlukla arpa, buğday, mısır gibi tahıllar farklı büyüklüklere sahip tepsilerde uygun 1sı, ışık ve nem altında çimlendirilmektedir. Tohumun çimlendirilip kısa sürede (7-8 gün) besin değeri yüksek, düşük maliyetli taze yeşil yem elde etmek için özel olarak geliştirilmiştir. Samanın üçte biri, yoncanın ise yedide biri kadar maliyete üretilebilen hidroponik yemler, yem giderlerinde \% 35-45 tasarruf sağlandığ sistemde tarla tarımında kullanılan suyun \% 3-5' i ile aynı miktarda yem üretilebilmektedir (Karaşahin, 2014; Baytekin 2015). Hidroponik ortamda büyümüş fideler; gür ve yumuşak yapraklar ve besleyici kök yapısı ile hayvanların severek tükettiği sindirilebilirliği, ham protein oranı, A ve D vitamini bakımından zengin yemlerdir (Sneath ve McIntosh, 2003; Sharif ve ark., 2013). Ayrıca, bu yemler hayvanlarda hastalıklara karşı direnci, döl tutma oranının arttırmakta ve hayvanlara daha yüksek enerji sağlamaktadır (Atıcı, 2012). Hidroponik ortamda çimlendirilen tahılların besin değeri üzerine yapılan araştırmalarda, yüksek konsantrasyonlarda klorofil ve proteaz, amilaz, lipaz, sitokrom, oksidaz, transhidrogenaz, superoksit dismutaz gibi farmakolojik enzimler ile apigenin, kuersetin, luteolin gibi bioflavonoidler içerdiği, vitamin A, B, C, E ve K bakımından zengin olduğu, kalsiyum, fosfor, potasyum, demir, magnezyum, sodyum, sülfür, çinko, bor, mangan, molibden, selenyum ile 17 farklı aminoasidin bulunduğu belirtilmiştir (Shukla ve ark., 2009; Mujoriya and Bodla 2011; Shah ve ark., 2011). Tane yemler yoğun olarak tüketildiklerinde içermiş oldukları konsantre besinler veya toksik bileşikler hayvan sağlığını tehdit edebilmektedir (Naik ve ark., 2012). Bu anlamada tanenin

7-10 gün süreyle çimlendirilmesiyle hem bu tür olumsuzlukların önüne geçilebilmekte hem de kısa sürede tanenin 10 katına kadar ağılıkta taze yem üretebilmektedir. Dolayısıyla bu teknoloji verimliliği artırmakta ve özellikle kurak bölgelerde veya kış aylarında hayvanların taze yem ihtiyaçlarının giderilmesi açısından büyük önem taşımaktadır.

Hidroponik sistemde, filizlerin yüksek su içeriğinden dolayı taze ağırlığın artmakta ancak kuru madde fotosentezle ikame edilemediğinden kuru ağırlık önemli ölçüde azalmaktadır. Bautista (2002), Morgan ve ark. (1992), Naik ve ark. (2013), hidroponik üretimde taze ağırlıkta 5-10 kat artışa rağmen kuru ağırlıkta önemli bir azalma olduğunu bildirmişlerdir. Fazaeli ve ark. (2012), yedinci günde hasat edilen arpanın kuru madde içeriğinin yüzde 15 'in altında olduğunu bildirmiştir. Ayrıca, hidroponik üretimde verim ve kalite; sistem yönetimi, kullanılan tohum çeşidi ve kalitesi, sulama süresi ve sıklığı, ön ıslatma süresi, bitki besi elementi varlığı, sıcaklık, nem oranı, 1ş1k yoğunluğu ve pozisyonu, tohum yoğunluğu ve yetiştirme süresi gibi özelliklerden etkilenmektedir. Hidroponik yemlerde hem kuru ağırlık kaybını azaltmak hem de verim ve kaliteyi artırmak için, tohum çimlenmesini ve fide büyümesini olumlu yönde etkileyen çeşitli priming uygulamaları (osmo ve hidro priming, farklı sicaklıklar, hormonlar ve bazı kimyasallar) bulunmaktadır (Yari ve ark. 2010). Bu priming uygulamalarından son zamanlarda yaygınlaşan biri de duman solüsyonlarıdır. Organik atıkların yakılarak dumanın suda tutulmasıyla elde edilen duman solüsyonları doğrudan tohuma uygulandığı gibi veya toprağa da uygulanmaktadır.

Bitki kaynaklı duman solüsyonları, yakılan bitkiye bağlı olarak, çimlenme ve fide büyümesi üzerinde önemli etkilere sahiptir (Jefferson ve ark., 2008; Lindon ve Menges, 2008; Dixon ve ark., 2009). Ayrıca duman solüsyonları yem bitkilerinin kalitesi ve verimi üzerinde olumlu etkileri olduğu bazı araştırmacılar tarafından da gösterilmiştir (Doğrusoz ve ark. 2019; Başaran ve ark. 2019). Duman solüsyonları bünyesinde fazla sayıda kimyasal bulunduğu ve çimlenme üzerindeki etkinin butenoloid (3-metil-2Hfuro [2,3-c] piran-2-on) ve yanmış selülozdan kaynaklandığ1 tespit edilmiştir (Van Staden ve ark. 2004; Flematti ve ark. 2004). Karrisinolid olarak da adlandırılan butenoloid, tohumların fitohormonlara, 1şığa gereksinimlerinde ve tohum kabuğu geçirgenliğinde değiş̧ikliğe neden olmaktadır.

$\mathrm{Bu}$ çalışma duman solüsyonu ile priming işleminin mürdümüğün hidroponik ortamda gelişmesi üzerine etkilerini dolayısıyla daha verimli ve kaliteli yem üretimine katkısını incelemek üzere yürütülmüştür.

\section{Materyal ve Yöntem}

Çalışma, 2019 yılında ve Yozgat Bozok Üniversitesi Ziraat Fakültesi bünyesindeki iklim odasında yürütülmüştür. Çalışmada, hidroponik yem üretimi için mürdümük tohumları materyal olarak kullanılmıştır. Mürdümük tohumlarına priming uygulaması için yulaf (Avena sativa L.) ve mürdümük (Lathyrus sativus L.) samanından elde edilmiş iki farklı duman solüsyonu kullanılmıştır. Duman solüsyonları, yulaf ve mürdümügün tohum hasadı sonrasında kalan samanlarının yakılmasıyla elde edilmiştir. Her iki tür içinde, $2 \mathrm{~kg}$ saman yakılarak özel düzenek yardımıyla 4L saf su içerisinde tutulmuştur (Ghebrehiwot ve ark., 2009; Başaran ve ark., 2019). Yakma işlemi sonrasında duman solüsyonları filtre kâğıdından süzülmüştür. Bu şekilde elde edilmiş stok 
solüsyonlardan 5 farklı konsantrasyon (\% 0, 1, 5, 10 ve 15) oluşturulmuştur. Çalışma her işlem üç tekrarlamalı olarak tesadüf blokları deneme deseninde oluşturulmuş ve her solüsyon için farklı bir deneme kurulmuştur. Her işlem için $100 \mathrm{~g}$ mürdümük tohumu \%10' lik sodyum hipoklorit çözeltisinde $5 \mathrm{dk}$ bekletilerek sterilize edilmiştir (Al-Karaki ve Al-Momani, 2011). Sterilizasyon sonrasında yıkanan tohumlar duman solüsyonlarının farklı konsantrasyonlarında 18 saat $22^{\circ} \mathrm{C}^{\prime}$ de bekletilerek priming işlemi tamamlanmıştır. Daha sonra tohumlar $3 \mathrm{kez}$ çeşme suyunda ve son olarak steril suyla y1kanarak hidroponik üretim için $15 \times 16 \times 5 \mathrm{~cm}$ kaplara yerleştirilmiştir. Denemeler iklim odasında 8 gün boyunca devam etmiştir (Şekil 1 ve 2). Denemeler ilk iki gün $25^{\circ} \mathrm{C}^{\prime}$ de karanlık şartlarda, kalan 6 günde ise $25^{\circ} \mathrm{C}^{\prime}$ de $16: 8$ saat aydınlı/karanlık fotoperiyort da tutulmuştur. Sulama günde 6 kez sprey halinde ve eşit miktarda yapılmıştır.
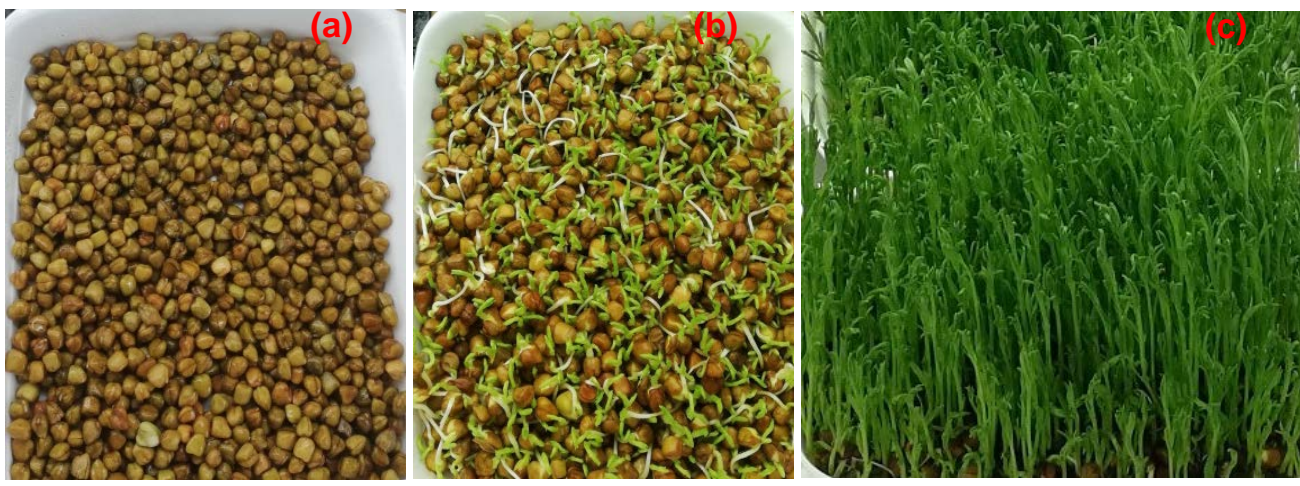

Şekil 1. Mürdümüğün hidroponik ortamda 1. (a) 4. (b) ve 8. (c) günlerdeki gelişimi

Figure 1. The development of grass pea in hydroponic environment on the 1st (a) 4th (b) and 8th (c) days

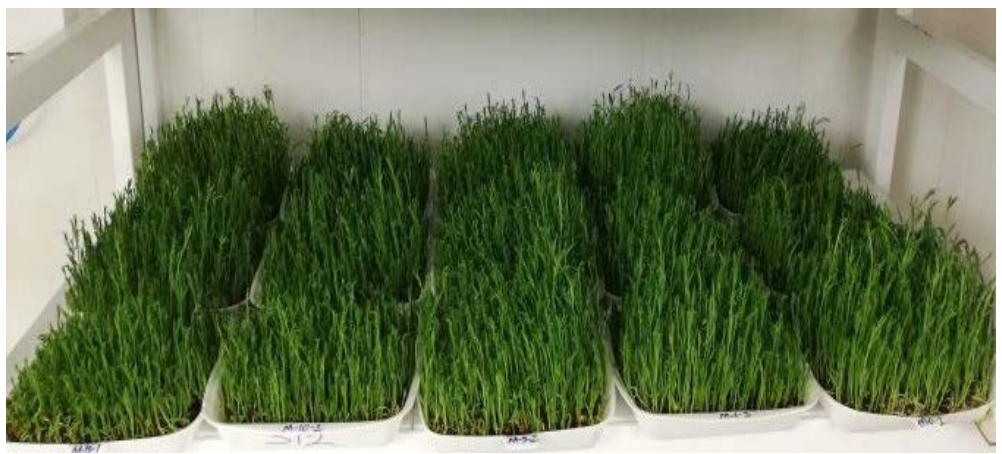

Şekil 2. Duman solüsyonu ile priming edilmiş mürdümügün hidroponik ortamda 8. gün genel görünümü

Figure 2. General view of grass pea primed with smoke solution on day 8 in hydroponic environment

Sekiz gün sonunda kaplardaki tüm bitki materyalleri alınarak $65^{\circ} \mathrm{C}^{\prime}$ de 48 saat kurutma kabininde kurutulmuş ve örnekler tartılarak kuru ağırlıkları g cinsinden elde edilmiştir. Kuru ağırlık (KA) hesaplanırken işleme ait tüm kapta bulunan filizler tartıldığ 1 için $\mathrm{g} /$ işlem cinsinden ifade edilmiştir. Kurutulmuş örnekler ot değirmeni ile öğütülerek $1 \mathrm{~mm}$ ' lik elekten geçirilmiştir. Ögütülmüş örnekler NIRS (Foss 6500) cihazında (near infrared reflectance spectroscopy; Silver Spring, MD, USA), IC0904FE programı ile ham protein (HP;\%), ADF (acid detergent fiber,\%), NDF (neutral detergent fiber;\%) ve mineral madde (Ca, P, K and Mg;\%) analizleri yapılmıştır. Ham protein verimi (HPV;g) ise ham protein oranı ile kuru ağılığın çarpılmasıyla elde edilmiştir. Başlangıç materyali olarak mürdümük tanesi ortalama \% 26.3 HP, \% 0.15Ca, \% 0.84 K, \% 0.16 Mg, \% 0.33 P, 87.2 ppm Fe, 10.05 ppm Cu ve 77.35 ppm Zn içermektedir.

Her iki denemede SPSS 20.0 paket programı ile ayrı ayrı tesadüf parselleri deneme desenine göre analiz edilmiş ve ortalamalar arasındaki fark S_Duncan çoklu karşıllaştırma testi ile incelenmiştir. 


\section{Bulgular ve Tartışma}

Farklı duman solüsyonları ve konsantrasyonları ile tohuma yapılan ön uygulamalar (priming) Hidroponik ortamda mürdümüğün kuru ağılık, ham protein oranı, ham protein verimi, ADF, ve NDF içeriklerine etkisi Çizelge 1' de, mineral madde içerikleri üzerine etkisi ise Çizelge 2' de verilmiştir.

Hidroponik ortamda çimlenme sürecinde taneye kıyasla kuru ağılık kaybı beklenen bir durumdur (Naik ve ark. 2013; Fazaeli ve ark. 2012). Nitekim, bu durum hidroponik üretimin en önemli sorunlarından birisidir. Başlangıç ağırlığı $100 \mathrm{~g}$ olan mürdümük tanelerinde sekiz günün sonunda kuru ağılık solüsyon kaynağından ve solüsyon x doz interaksiyonundan etkilenmemiştir. Ancak kuru ağırlık mürdümük solüsyonunda ortalama $92.11 \mathrm{~g} /$ işlem iken yulaf solüsyonunda ise göreceli olarak daha düşük ve ortalama $91.83 \mathrm{~g} /$ işlem olmuştur. Benzer şekilde, önemli olmamakla birlikte, solüsyon uygulaması tüm dozlarda kontrolün $(89.62 \mathrm{~g} /$ işlem) üzerinde kuru ağırlığa sahip olmuştur (Çizelge 1).

Çizelge 1. Farklı kaynaklardan elde edilmiş duman solüsyonlarının hidroponik ortamda mürdümüğün kuru ağırlık, ham protein oranı, ham protein verimi, ADF ve NDF içeriklerine etkisi

Table 1. The effect of smoke solutions obtained from different sources on dry weight, crude protein ratio, crude protein yield, ADF and NDF contents of grass pea in hydroponic environment.

\begin{tabular}{|c|c|c|c|c|c|c|}
\hline \multicolumn{2}{|c|}{$\begin{array}{c}\text { Dozlar } \\
(\%)\end{array}$} & $\begin{array}{c}\text { KA } \\
\text { g/işlem }\end{array}$ & $\begin{array}{c}\text { HP** } \\
\%\end{array}$ & $\begin{array}{c}\mathbf{H P V}^{*} \\
\mathbf{g}^{\#}\end{array}$ & $\begin{array}{c}\text { ADF }^{*} \\
\%\end{array}$ & $\begin{array}{c}\text { NDF } \\
\%\end{array}$ \\
\hline \multirow{6}{*}{ 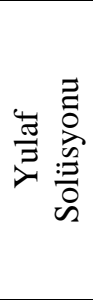 } & 0 & 89.62 & $33.03 \mathrm{~b}$ & $29.60 \mathrm{c}$ & $18.75 \mathrm{a}$ & 24.33 \\
\hline & 1 & 96.19 & $35.10 \mathrm{a}$ & 33.76 a & $17.46 \mathrm{ab}$ & 21.21 \\
\hline & 5 & 90.48 & 35.86 a & $32.45 \mathrm{ab}$ & 16.29 bc & 20.76 \\
\hline & 10 & 90.00 & 35.52 a & 31.97 abc & $15.62 \mathrm{bc}$ & 21.83 \\
\hline & 15 & 92.86 & $36.10 \mathrm{a}$ & $33.52 \mathrm{a}$ & $16.64 \mathrm{bc}$ & 19.87 \\
\hline & Ort. & 91.83 & $35.12 A^{*}$ & $32.26 \mathrm{~A}^{*}$ & 16.95 & 21.60 \\
\hline \multirow{6}{*}{ 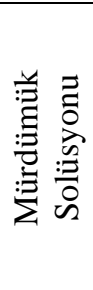 } & 0 & 89.62 & $33.03 \mathrm{~b}$ & $29.60 \mathrm{c}$ & $18.75 \mathrm{a}$ & 24.33 \\
\hline & 1 & 92.27 & $33.12 \mathrm{~b}$ & 30.56 bc & 17.28 abc & 20.04 \\
\hline & 5 & 94.42 & $33.32 \mathrm{~b}$ & $31.46 \mathrm{abc}$ & 16.73 bc & 20.40 \\
\hline & 10 & 91.96 & $32.91 \mathrm{~b}$ & 30.26 bc & 15.63 bc & 19.37 \\
\hline & 15 & 92.26 & $34.84 \mathrm{a}$ & 32.14 abc & $15.16 \mathrm{c}$ & 15.88 \\
\hline & Ort. & 92.11 & $33.44 B$ & $30.81 \mathrm{~B}$ & 16.71 & 20.00 \\
\hline
\end{tabular}

\#: işleme ait tüm bitki materyalindeki protein verimini ifade etmektedir. ${ }^{*}: \mathrm{P}<0.05$; ${ }^{* *}: \mathrm{P}<0.01$, aynı harfle gösterilen ortalamalar arasinda fark yoktur $(\mathrm{p}<0.05)$.

Mürdümük filizlerinin ham protein oranı üzerinde solüsyon kaynağ $1(\mathrm{p}<0.05)$ ve solüsyon $\mathrm{x}$ doz interaksiyonu $(\mathrm{p}<0.01)$ önemli olmuştur. Solüsyon kaynakları kıyaslandığında yulaf solüsyonunda mürdümük solüsyonundan daha yüksek ortalama protein oranı $(\%$ 35.12) belirlenmiştir. Yulaf solüsyonunun tüm dozları protein oranı bakımından aynı gurupta ve kontrolden (\% 33.03) yüksek olmuştur. Mürdümük solüsyonunu uygulamasında ise en yüksek protein oranı $\% 15^{\prime}$ lik konsantrasyonda elde edilmiş, diğer dozlar kontrolle aynı grupta yer almışlardır. Ham protein verimi de solüsyon kaynaklarından önemli derecede $(p<0.05)$ etkilenmiş ve ortalama olarak yulaf solüsyonunda (32.26 g/KA) daha yüksek olmuştur. Ayrıca, ham protein verimi (HPV) bakımından kaynak x doz inreaksiyonu önemli $(\mathrm{p}<0.05)$ bulunmuştur. Buna göre duman solüsyonu uygulamasında bütün dozlarda kontrolden $(29.60 \mathrm{~g} / \mathrm{KA})$ daha yüksek HPV tespit edilmiştir. Hidroponik ortamda yetiştirilen mürdümük filizlerinin ADF ve NDF içeriği üzerinde solüsyon kaynağı önemli bir etki göstermemiştir. Buna karşın ADF içeriği üzerinde kaynak $\mathrm{x}$ doz interaksiyonu önemli $(\mathrm{p}<0.05)$ bulunmuş ancak, özellikle yüksek dozlarda $(>\% 1)$ duman solüsyonu uygulamalarında kontrolden (\% 18.75 daha düşük değerler elde edilmiştir. (Çizelge 1).

Mürdümük filizlerinin mineral madde içeriği üzerinde hem solüsyon kaynağı $(\mathrm{p}<0.01)$ hem de solüsyon $\mathrm{x}$ doz interaksiyonu $(\mathrm{p}<0.05, \mathrm{p}<0.01)$ önemli olmuştur (Çizelge 2$)$. Mürdümük kaynaklı solüsyon uygulandığında yulaf solüsyonuna göre incelenen tüm elementler daha yüksek ortama değere sahip olmuştur. Filizlerin Ca içeriği, yulaf solüsyonu uygulanan tüm işlemlerde kontrolden düşük mürdümük uygulananlar da ise yüksek olmuş, solüsyon dozları arsında ise farklılık gözlenmemiştir. Benzer şekilde yulaf solüsyonu diğer incelen elementleri de olumsuz etkilemiş ve $\mathrm{K}, \mathrm{Mg}, \mathrm{P}$ ve $\mathrm{Fe}$ içeriğinde kontrolden daha düşük değerlere yol açmıştır. Ancak yulaf solüsyonu $\mathrm{Cu}$ içeriği bakımından \% 5 ve 15 konsantrasyonlarda, Zn içeriği ise \%15 konsantrasyonda kontrolle aynı grupta yer almıştır (Çizelge 2). 
Çizelge 2. Farklı kaynaklardan elde edilmiş duman solüsyonlarının hidroponik ortamda mürdümüğün mineral madde üzerine etkisi

Table 2. The effect of smoke solutions obtained from different sources on mineral contents of grass pea in a hydroponic environment.

\begin{tabular}{|c|c|c|c|c|c|c|c|c|}
\hline \multicolumn{2}{|c|}{$\begin{array}{c}\text { Dozlar } \\
(\%)\end{array}$} & $\begin{array}{c}\text { Ca** } \\
\%\end{array}$ & $\begin{array}{c}\mathrm{K}^{* *} \\
\%\end{array}$ & $\begin{array}{c}\text { Mg** } \\
\%\end{array}$ & $\begin{array}{c}\mathrm{P} * * \\
\% \\
\end{array}$ & $\begin{array}{l}\mathrm{Fe}^{* *} \\
\mathrm{ppm} \\
\end{array}$ & $\begin{array}{l}\text { Cu* } \\
\text { ppm } \\
\end{array}$ & $\begin{array}{c}\mathrm{Zn} * * \\
\text { ppm } \\
\end{array}$ \\
\hline \multirow{6}{*}{ 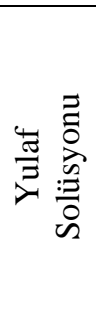 } & 0 & $0.15 \mathrm{~b}$ & $0.81 \mathrm{abc}$ & $0.15 \mathrm{a}$ & $0.36 \mathrm{abc}$ & $71.99 \mathrm{a}-\mathrm{d}$ & $8.92 \mathrm{abc}$ & $92.13 \mathrm{ab}$ \\
\hline & 1 & $0.10 \mathrm{c}$ & $0.56 \mathrm{~d}$ & $0.08 \mathrm{~b}$ & $0.24 \mathrm{de}$ & $61.14 \mathrm{de}$ & $6.30 \mathrm{c}$ & $74.43 \mathrm{c}$ \\
\hline & 5 & $0.10 \mathrm{c}$ & $0.66 \mathrm{~cd}$ & $0.10 \mathrm{~b}$ & 0.29 cde & 64.23 cde & $8.62 \mathrm{abc}$ & 81.48 bc \\
\hline & 10 & $0.09 \mathrm{c}$ & $0.53 \mathrm{~d}$ & $0.08 \mathrm{~b}$ & $0.23 \mathrm{e}$ & $57.86 \mathrm{e}$ & $7.31 \mathrm{bc}$ & $72.78 \mathrm{c}$ \\
\hline & 15 & 0.12 c & 0.72 bcd & $0.11 \mathrm{~b}$ & $0.32 \mathrm{bcd}$ & 69.79 b-e & $9.88 a b$ & 86.75 abc \\
\hline & Ort.** & $0.11 B$ & $0.66 B$ & $0.10 B$ & $0.29 B$ & $65.00 \mathrm{~B}$ & $8.21 B$ & $81.51 \mathrm{~B}$ \\
\hline \multirow{6}{*}{ 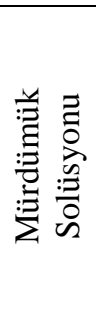 } & 0 & $0.15 \mathrm{~b}$ & $0.81 \mathrm{abc}$ & $0.15 \mathrm{a}$ & $0.36 \mathrm{abc}$ & 71.99 a-d & $8.92 \mathrm{abc}$ & $92.13 \mathrm{ab}$ \\
\hline & 1 & $0.21 \mathrm{a}$ & $0.92 \mathrm{ab}$ & 0.19 a & $0.39 a b$ & 83.33 a & $10.51 \mathrm{a}$ & $100.37 \mathrm{a}$ \\
\hline & 5 & $0.18 \mathrm{ab}$ & $0.89 a b$ & $0.19 \mathrm{a}$ & $0.39 \mathrm{ab}$ & $77.77 \mathrm{ab}$ & $9.94 \mathrm{ab}$ & $96.80 \mathrm{ab}$ \\
\hline & 10 & $0.19 a b$ & $0.96 \mathrm{a}$ & $0.19 \mathrm{a}$ & $0.42 \mathrm{a}$ & $79.81 \mathrm{ab}$ & 10.69 a & $97.31 \mathrm{ab}$ \\
\hline & 15 & $0.18 a b$ & $0.84 \mathrm{abc}$ & $0.17 \mathrm{a}$ & $0.36 \mathrm{abc}$ & 75.00 abc & $9.63 \mathrm{ab}$ & $92.71 \mathrm{ab}$ \\
\hline & Ort.** & $0.18 \mathrm{~A}$ & $0.88 \mathrm{~A}$ & $0.18 \mathrm{~A}$ & $0.38 \mathrm{~A}$ & $77.58 \mathrm{~A}$ & $9.94 \mathrm{~A}$ & $95.91 A$ \\
\hline
\end{tabular}

$*: \mathrm{P}<0.05 ; * *: \mathrm{P}<0.01$, aynı harfle gösterilen ortalamalar arasında fark yoktur $(\mathrm{p}<0.05)$.

Hidroponik ortamda yetiştirilen mürdümük filizlerinde sekizinci günün sonunda taneye oranla, kuru ağırlık ve kimyasal içerik bakımından önemli değişiklikler tespit edilmiştir. Bu açıdan kuru ağılık azalmış, protein ve mineral madde içeriği ise artmıştır. Benzer sonuçlar daha önce de birçok araştırıcı tarafindan bildirilmiştir (Bautista 2002; Morgan ve ark. 1992; Naik ve ark. 2013; Fazaeli ve ark. 2012). Duman solüsyonu uygulamaları incelen özellikler üzerinde etkili olmuş ve genellikle olumlu sonuçlar doğurmuştur. Duman solüsyonu uygulanan işlemlerde kontrole oranla kuru ağırlık kaybı azalmış, protein ve mineral madde içeriği ise artmıştır. Buna göre hidroponik ortamda duman solüsyonu uygulamaları mürdümüğün beslenme değerinin artmasına katkı sağlamıştır. Ancak duman solüsyonunun hazırlanmasında kullanılan bitki ve solüsyonun dozuda incelenen özellikler, özellikle kimyasal özellikler üzerinde etkili olmuştur. Ortalama değerlere bakıldığında yulaf kaynaklı solüsyon protein oranı ve veriminde, mürdümük kaynaklı solüsyon ise mineral madde içeriğinde daha etkili olmuştur. Duman solüsyonlarının çimlenme ve fide büyümesi üzerine uyarıcı etkisi birçok çalışmada (Ghebrehiwot ve ark., 2012) tespit edilmiştir. Oluşan bu etkiler duman solüsyonlarının kaynağına ve konsantrasyonuna bağlı olarak önemli ölçüde değişmekte (Kulkarni ve ark. 2007:: Mojzes ve Kalapos, 2014; Aslam ve ark., 2015; Abu ve ark., 2016), olumlu etikler genellikle düşük dozlarda tespit edilirken yüksek dozların toksik etki gösterdiği bildirilmektedir. Abedi ve ark. (2018) tarafından yapılan bir çalışmada, duman solüsyonu konsantrasyonlarının (1: 1000 ve 1: 500, v/ v) farklı türler üzerinde farklı şekilde etkilendiğini belirtilmiştir. Catav ve ark. (2012), ise duman solüsyonlarının bazı bitkilerde etkisiz olduğu ve özellikle yüksek konsantrasyonlarda toksik etkiye sahip olduğu belirlenmiştir. Bitkisel kaynaklı duman solüsyonlarının bu değişken etkileri açıkça gösterilmiş olmasına rağmen, bitki büyümesini nasıl etkilediği bilinmeyen birçok kimyasala sahip olmasından (Sriharti ve ark., 2020) dolayı, net olarak bilinmemektedir. Mevcut çalışmada olumlu etkiler genellikle yüksek dozlarda tespit edilmiştir. Bu durum duman solüsyonun hazırlanmasında kullandığımız bitiklerden veya çözelti konsantrasyonlarımızdan kaynaklanmış olabilir. Özellikle konsantrasyon değişken bir özellik olup stok çözeltiye yani ne kadar bitkinin yakıldığ 1 ve dumanın ne kadar suda tutulduğuyla ilişkilidir. Yani doz genellikle çalışmaya özgü bir değeri ifade etmektedir. Bu bakımdan çalışmalar arasında farklılıkların olmasını beklenen bir durumdur. Bu durum duman solüsyonu çalışmalarında kaynak ve dozun önemini göstermekte ve beklenen olumlu etki için türe özgü çalışmaların gereğini ortaya koymaktadır.

Duman solüsyonunun farklı bitkilerde filizlerinin kuru ağlık üzerine pozitif etkisi Kulkarni ve ark. (2007) ve Başaran ve ark. (2019) tarafindan da bildirilmiştir. Filizlerin ham protein oranı ve ham protein verimi duman solüsyonu konsantrasyonlarından önemli ölçüde etkilenmiş ve yulaf kaynaklı solüsyon mürdümük solüsyonundan daha etkili olmuştur. Duman solüsyonu uygulanan işlemlerin ham protein verimi kontrolden yüksek olmuştur. Bitkisel kaynaklı duman solüsyonu ile priming işleminin misırda (Waheed ve ark. 2016, Aslam ve ark. 2019) ve mürdümükte (Başaran ve ark. 2019) protein içeriğini arttırmıştır. Jamil ve ark. (2020), düşük konsantrasyonlarda duman solüsyonu ile priming edilen pirinç tohumlarında protein ve karbonhidrat içeriğinin arttığını tespit etmişlerdir. 


\section{Sonuç}

Çalışmada, bitki kaynaklı duman solüsyonları ile priming işleminin hidroponik ortamda yetiştirilen mürdümük üzerine etkinliği incelenmiştir. Bu amaçla yulaf ve mürdümük hasat artıklarının yakılarak elde edildiği iki farklı duman solüsyonu ve farklı konsantrasyonları değerlendirilmiştir. Genel olarak, hidroponik üretim sistemi üzerinde duman çözeltileri ile primin işleminin olumlu ve uyarıcı etkilerinin olduğu tespit edilmiştir. Elde edilen sonuçlara göre kuru ağırlık üzerine her iki kaynağında pozitif etki yaptığı ve ham protein oranı ve veriminde ise yulaf kaynaklı duman solüsyonun daha etkili olduğu belirlenmiştir. Ancak mineral madde içeriğinde mürdümük solüsyonunun teşvik edici olmasına karşın yulaf solüsyonu olumsuz etki göstermiştir. Sonuç olarak mürdümük tohumlarına kendi hasat artığından elde edilen duman solüsyonu ile priming işlemi uygulandığında hidroponik ortamda daha kaliteli ve verimi yüksek bir yem elde edilebileceği ortaya konmuştur.

\section{Teşekkür}

Bu çalışma 6602a-ZF / 18-240 proje numarası ile Yozgat Bozok Üniversitesi Bilimsel Araştırma Proje Müdürlüğü tarafından desteklenmiştir.

\section{Kaynaklar}

Abu, Y., Romo, J.T., Bai, Y., Coulman, B., 2016. Priming seeds in aqueous smoke solutions to improve seed germination and biomass production of perennial forage species. Can. J. Plant Sci. 96:551-563.

Abedi, M., Zaki, E., Erfanzadeh, R., Naqinezhad, A., 2018. Germination patterns of the scrublands in response to smoke: The role of functional groups and the effect of smoke treatment method. South African Journal of Botany, 115:231-236.

Al-Karaki, G.N., Al-Momani, N. 2011. Evaluation of some barley cultivars for green fodder production and water use efficiency under hydroponic conditions. Jordan Journal of Agricultural Sciences, 7(3):448-457.

Aslam, M., Jamil, M., Khaton, A., Salah, E.E.H., Nasser, A.A.S., Shakirullah, K.S., Ijaz, M., Shafiq, U.R., 2015. Does weeds-derived smoke improve plant growth of wheat. Journal of Bio-Molecular Sciences (JBMS), 3(2):8696.

Aslam, M., Rehman, S., Khatoon, A. Jamil, M. Yamaguchi, H. Hitachi, K. Tsuchida, K. Li, X. Sunohara, Y. Matsumoto, H., Komatsu, S., 2019. Molecular Responses of Maize Shoot to a Plant Derived Smoke Solution. Int. J. Mol. Sci. 20, 1319.

Atıc1, K.D., 2012. Hasılmatik yem derdini ortadan kaldırıyor. Tarım Gündem Dergisi, Sayı 9 (Temmuz-Ağustos), Sayfa:96-97.

Baytekin, H., 2015. Kaba yeme alternatif lazım. Erişim adresi: http://bigagunlugu.com/yazarDetay.aspx?yazarID=5\&haberI D=3987 Erişim tarihi: 01.04.2015

Basaran, U., Dogrusoz, M., Gulumser, E., Mut, H., 2019. "Using smoke solutions in grass pea (Lathyrus sativus L.) to improve germination and seedling growth and to reduce toxic compound ODAP". Turkish Journal of Agriculture and Forestry, 43:518-526

Bautista, S.H., 2002. Producción de forraje verde hidropónico de trigo Triticum aestivum L. para el mantenimiento de conejos criollos Oryctolagus cuniculus. MSc thesis, Universidad Autónoma de Guerrero (UAG) Chilpancingo, Guerrero, México.

Catav, S.S., Bekar, I., Ates, B.S., Ergan, G., Oymak, F., Ulker, E.D., Tavsanoglu, C., 2012. Germination response of five eastern Mediterranean woody species to smoke solutions derived from various plants. Turk J Bot 36: 480487.

Dixon, K.W., Merritt, D.J., Flematti, G.R., Ghisalberti, E.L., 2009. Karrikinolide - a phytoreactive compound derived from smoke with applications in horticulture, Ecological Restoration and Agriculture. Acta Hortic, 813:155-170.

Dogrusoz, M., Gulumser, E., Basaran, U., Mut, H., 2019. The Effect of smoke solutions on the germination and seedling growth of common vetch (Vicia sativa L.) and grass pea (Lathyrus sativus L.) 2nd international scientific research congress, 27-29 September, Kayseri, s:97-105.

Fazaeli, H., Golmohammadi, H.A., Tabatabayee, S.N., Asghari-Tabrizi, M., 2012. Productivity and Nutritive Value of Barley Green Fodder Yield in Hydroponic System. World Applied Sciences Journal, 16(4):531-539.

Flematti, G.R., Ghisalberti, E.L., Dixon, K.W., Trengove, R.D., 2004. A compound from smoke that promotes seed germination. Science, 305:977. 
Ghebrehiwot, H.M., Kulkarni, G.M., Kirkman, K.P., Van Staden, J., 2009. Smoke solutions and temperature influence the germination and seedling growth of South African Mesic Grassland Species, Rangeland Ecology \& Management, 62(6):572-578.

Jamil, M., Jahangir, M., Rehman, S.U., 2020. Smoke induced physiological, biochemical and molecular changes in germinating rice seeds. Pak. J. Bot., 52(3): 865-871.

Jefferson, L.V., Pennacchio, M, Havens, K., Forsberg, B., Sollenberger, D. 2008. Ault J Ex situ germination responses of Midwestern USA prairie species to plant-derived smoke. Am. Midl. Nat. 159:251-256.

Karasahin, M., 2014. Effects of Different Applications on Dry Matter and Crude Protein Yields in Hydroponic Barley Grass Production As a Forage Source. Suleyman Demirel University, Journal of Agriculture Faculty 9(1):27-33.

Kulkarni, M.G., Ascough, G.D., Van Staden, J., 2007. Effects of foliar applications of smoke-water and a smokeisolated butenolide on seedling growth of okra and tomato. HortScience 42:179182.

Lindon, H.L., Menges, E., 2008. Effects of smoke on seed germination of twenty species of fire-prone habitats in Florida. Castanea 73:106-110.

Mojzes, A., Kalapos, T., 2014. Plant-derived smoke stimulates germination of four herbaceous species common in temperate regions of Europe. Plant Ecol., 215:411-415.

Morgan, J., Hunter, R.R., O'Haire, R., 1992. Limiting factors in hydroponic barley grass production. In the proceeding of the 8th International congress on soil less culture, 241-261.

Mujoriya, R., Bodla, R.B., 2011. A study on wheat grass and its nutritional value. Food Science and Quality Management, 2:1-8.

Naik, P.K., Dhuri, R.B., Swain, B.K., Singh, N.P., 2012. Nutrient changes with the growth of hydroponics fodder maize. Indian Journal of Animal Nutrition, 29(2):161-163.

Naik, P.K., Dhuri, R.B., Karunakaran, M., Swain, B.K., Singh, N.P., 2013. Hydroponic technology for green fodder production. Indian Dairyman 65: 54-58.

Shah, K.V., Kapupara, P.K., Desai, T.R., 2011. Determination of sodium, potassium, calcium and lithium in a wheat grass by flame photometry. Pharma Science Monitor An International Journal of Pharmaceutical Sciences 900909.

Sharif, M., Hussain, A., Subhani, M., 2013. Use of sprouted grains in the diets of poultry and ruminants Indian Journal of Research 2(10):4-7.

Shukla, V., Vashistha, M., Singh, S.N., 2009. Evaluation of antioxidant profile and activity of amalaki (Emblica officinalis), spirulina and wheat grass. Indian Journal of Clinical Biochemistry 24(1):70-75.

Sneath, R., Mclntosh, F. 2003. Review of hydroponic fodder production for beef cattle. Queensland Government, Department of Primary Industries, Dalby, Queensland.

Sriharti, Indriati, A., Dyah, S., 2020. Utilization of liquid smoke from cocoa pod husk (Theobroma cocoa L) for germination of red seed (Capsicum annum L). Asian Journal of Applied Sciences (ISSN: 2321 - 0893), Volume 08 - Issue 01, 1-11.

Van Staden, J., Jäger, A.K., Light, M.E., Burger, B.V, 2004. Isolation of the majör germination cue from plantderived smoke. South African Journal of Botany 70, 654-659.

Waheed, M.A., Muhammad, J., Muhammad, D.K., Shakirullah, K.S., UrRehman, S., 2016. Effect of plant-derived smoke solutions on physiological and biochemical attributes of maize (Zea mays L.) under salt stress. Pak J Bot 48:1763-1774.

Yari, L., Aghaalikhani, M., Khazaei, F., 2010. Effect of Seed priming duration and temperature on seed germination behavior of bread wheat (Triticum aestivum L.). ARPN Journal of Agricultural and Biological Science 5(1):5-8. 